\title{
Fifteen years looking at the mirror: On the presence of PISA in education policy processes (Portugal, 2000-2016)
}

\section{Luís Miguel Carvalho | Estela Costa | Catarina Gonçalves}

Universidade de Lisboa, Instituto de Educação, Alameda da Universidade, Lisbon, Portugal

\section{Correspondence}

Luís Miguel Carvalho, Universidade de Lisboa, Instituto de Educação, Alameda da Universidade, Lisbon, Portugal.

Email: Imcarvalho@ie.ulisboa.pt

\begin{abstract}
This article describes and discusses what happens when knowledge for policy generated within PISA is received by its target audience: what have the Portuguese policy actors been doing with PISA data and analysis when they consider, express and justify their choices? Drawing on previous and current studies, using interview materials and formal and informal policy documents, as well as texts published in the written press, the article analyses two main phenomena related to the reception of PISA and how this has evolved between 2001 and 2012 in Portugal: the consolidation of PISA's credibility as a source for policy processes and texts; the emergence of new actors and modes of intervention in the production of knowledge for national policy, drawing on PISA. Finally, it presents an analysis of the reception of PISA 2015 in the Portuguese media, focusing on the interventions by political actors in the Portuguese daily and weekly written press. Two main elements emerge from our content analysis as the main common elements of that reception: the consecration of PISA's credibility; and the practices of qualification and disqualification of educational policies and perspectives. The article concludes by emphasising the regulatory role of PISA in Portuguese policy processes and the relevant contribution played by the politics of reception in legitimising this role.
\end{abstract}

\section{KEYWORDS}

education policy, ILSA, knowledge-policy relationship, PISA, Portugal

\section{1 | INTRODUCTION}

PISA was like a mirror. Each time its results came out, Portugal saw itself in the mirror. In comparison with others who were in the picture, we were saying, 'Well, we are not as tall as we thought, not as skinny or as fat or as handsome as we thought. We need to work to get taller and look nicer in this image.' (Former Minister of Education, 2012). (www.oecd.org/pisa/pisaproducts/videoseriesstrongperformersandsuccessfulreformersineducation.htm). 
The use of the mirror metaphor which describes the reception of the PISA data at the national level takes the first few seconds of a video by OECD and the Pearson Foundation on the Portuguese education system, as part of the series Strong Performers and Successful Reformers in Education. This series aims to 'highlight initiatives taken by education authorities worldwide to help school students do better'. It is worth noting that this metaphor has often been used by those who are in charge of PISA:

(...) we are more like a mirror. We have a mirror; you can look at it and you can see how the world looks (...) (OECD official, Interview, 2009, cited in Carvalho \& Costa, 2009, p.137).

PISA shows what is possible in education, and it helps countries see themselves in the mirror of the education opportunities and results delivered by the world's leaders in education (OECD's Deputy Director for Education and Skills, 2013) (http://all4ed.org/debunking-seven-myths-about-pisa).

From an analytical point of view, the power of this 'mirror' which OECD cyclically brings back to national politicians' sight resides in what it aims to display (students' performances in tests as indicators of school systems' quality-equity), in the credibility it holds and which it employs to attract those who might wish to look at themselves and be seen through it, but also in its multiple uses (Carvalho, 2014). Indeed, the reference to these multiple and recurring uses is present across the literature on the reception and effects of PISA in the national European contexts (Carvalho \& Costa, 2016): there is an assignation of multiple purposes to PISA texts and objects, particularly of legitimation (of reforms, policies, instruments), information (either as primary or as complementary source for the steering of education systems), and idealisation (supporting the construction of diverse educational ideals or narratives); PISA objects/texts are re-interpreted, made acceptable and efficient for each socio-cognitive context, thus, subject to diverse selections (e.g., regarding the policy domains addressed by PISA recommendations). Despite the persistent existence of critical voices, PISA is usually perceived as capable of raising public awareness, identifying problems and providing good examples, and accurately portraying the weaknesses and strengths of national systems. These perceptions come with the adoption of evidence-based approaches, even if, in some cases, as a phony adoption or as part of a categorical script for policy-making.

This article describes and discusses the proximity/distance of the Portuguese case in relation to the identified tendencies and the continuities/discontinuities in the way actors who are involved in the public policies relate to PISA. It questions what happens when the knowledge for policy generated within PISA is transmitted to its political audience and/or when the latter calls upon the former. What have the policy actors been doing with PISA data and analysis when they consider, express and justify their choices? How do they look at 'the mirror', how do they observe themselves in it and what do they say about what they see, each time OECD turns the polished face of PISA to the national spaces? The article draws on research conducted by one of its authors on the debate held by politicians in Portugal in the contexts of the first three PISA cycles (2000, 2003, and 2006), particularly on interviews conducted with three Ministers of Education (Afonso \& Costa, 2011), and research conducted more recently by the authors on how policymakers' relationships with PISA have evolved in the surveys that followed (2009, 2012, and 2015), using formal and informal policy documents (laws, government decrees, ministerial speeches, official press releases, information displayed in the official websites) as major sources and a collection of texts published in the written press for the analysis of the reception of PISA 2015.

This article first focuses on how PISA is received, considering the debate around it and how this has evolved from the 2001 to the 2012 PISA editions. Two lines are developed: the consolidation of PISA's credibility as a source for the production of statements on the educational system and policies; and the emergence of new actors and modes of intervention in the production of knowledge for national policy, drawing on PISA. It then presents an analysis of the reception of PISA 2015 in the Portuguese press, following the release of its last cycle results. Two lines are developed: the reception of the 2015 data as a moment of the consecration of PISA's credibility; and the practices of qualification and disqualification of educational policies and perspectives, which emerge as the main common elements of that reception. It concludes with the main points from the analysis developed in each section. 


\section{I THE RECEPTION OF PISA IN THE PORTUGUESE POLICY PROCESSES: TWO TRENDS}

We analyse the trajectory of PISA's political reception in Portugal according to two descriptive and interpretative lines: (a) from an unsure participation to a legitimating mobilisation; and (b) the difficult transformation of comparative knowledge for policy into knowledge for national policy.

\subsection{From an unsure participation to a legitimating mobilisation: signs of consolidation}

The reception of PISA in the political processes in Portugal was marked by an initial unsure participation, more for reasons related to political circumstances than as a result of a rational valorisation of this specific assessment instrument (Afonso \& Costa, 2011). Indeed, the first participation in PISA happened in a context in which the consideration of student performance as an indicator of the system's quality had just been incorporated in the educational agenda, and also in the aftermath of an undisputed negative perception of the Trends in International Mathematics and Science Study (TIMSS) results, published in 1996.

Doubts and debates around the decision to participate in PISA are perceptible in this recollection of the Minister of Education who was involved in the first PISA cycle:

Initially there was [in the Ministry] on the part of some sectors a reaction, I would say, negative regarding PISA. (...) I do not say that there were large sectors who were against an international comparison, what I think is that maybe there was the idea of: "First, let's try to create conditions and solve some problems that are apparently easy to solve, and then we move forward" (Former Minister of Education, Interview \#1, 2008).

More recently, in an activity report of the 19th Portuguese Government [2011-2015], PISA results were used in a very different way. In the first pages, the document presents a figure with no description or analysis whatsoever (Fig. 1) in which the variation of PISA results is shown as the series according to which the reader will judge the effect of educational policies of governments with different orientations: political measures taken by centre-left governments (1995-2001, 2005-2011), targeting the curriculum with specific programmes for improvement in maths and reading, from 2006 on; the introduction of national exams in the ninth grade by those governments, but which was legislated by previous centre-right governments [2001-2005] and which was reinforced by the departing government [20112015].

From the hesitation at the time of adhesion to the implicit acceptance of the performance of Portuguese students who were selected to be included in the assessed sample group as the reference indicator for the legitimating/'delegitimating' of policies, there was a consolidation of PISA in Portugal, especially from 2005 on. We identify two indicators that support this statement: the persistent use of PISA outcomes to justify the adoption of public policies; the activation of OECD scripts on the meanings and processes for the governing of education, in the context of enunciations in which policy-makers justify or encourage the use of PISA.

Regarding the first, we find a large list of policy areas in which PISA has been invoked (Table 1). Some of these interventions are not new in the Portuguese system, namely those regarding Mathematics, Science and the national language that may be considered to be in line with the political measures of the 1990s (Fernandes, 2014). This reinforces the idea that the invocation of international expertise associated with PISA emerges as a relevant resource for the 'certification' (Steiner-Khamsi, 2004) of interventions in the national policy processes.

A measure which was legitimised with PISA and that constituted a change in the Portuguese context was 'The Programme for Training in Experimental Teaching of Science for Primary School Teachers'. Running from 2006 to 2008, it was intended to promote students' scientific literacy through the generalisation of experimental teaching. Comprising higher education institutions with responsibility for initial teacher training, primary schools and school clusters, it was directed to the preparation, execution and discussion with and by the teachers of the activities to be developed in classroom, as well as the supervision sessions of classroom practices. 


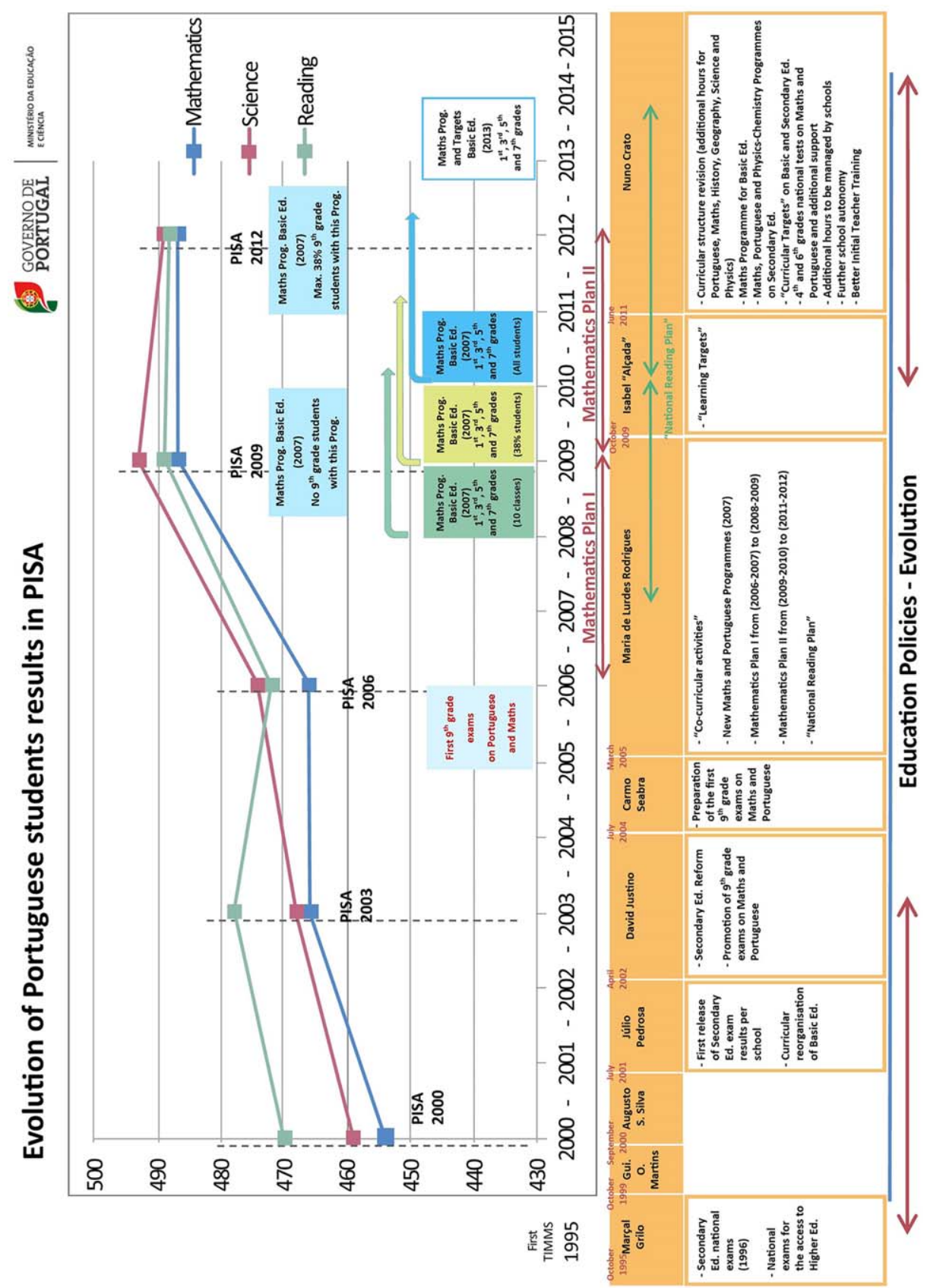

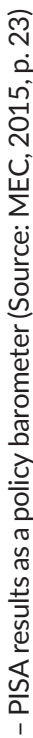

럼ำ 
TABLE 1 Policy proposals invoking PISA

\begin{tabular}{|c|c|c|}
\hline Areas & Policy proposals & Year \\
\hline \multirow[t]{6}{*}{ Curriculum } & The Mathematics Action Plan & 2005 \\
\hline & The National Reading Plan & 2006 \\
\hline & $\begin{array}{l}\text { Educational territories of priority intervention } \\
\text { program (re-launch) }\end{array}$ & 2006 \\
\hline & The 'Full-time school' program & 2008 \\
\hline & $\begin{array}{l}\text { The Programme and Curricular targets of } \\
\text { Mathematics }\end{array}$ & 2013 \\
\hline & $\begin{array}{l}\text { The Programme and Curricular targets of } \\
\text { Portuguese }\end{array}$ & 2014 \\
\hline ICT & The Technological Plan & 2007 \\
\hline \multirow[t]{2}{*}{ Initial and in-service teacher training } & $\begin{array}{l}\text { The Programme for Training in Experimental } \\
\text { Teaching of Science for Primary School } \\
\text { Teachers }\end{array}$ & 2005 \\
\hline & $\begin{array}{l}\text { The National Programme for Portuguese } \\
\text { Language Teaching in Primary Education }\end{array}$ & 2006 \\
\hline
\end{tabular}

Regarding the second, one can observe the enactment of the dicta about the (rational) decision maker who rules focusing on data about the outputs and outcomes of the system, with/through a comparative reason, and within a global cooperative and competitive space. The following quotes illustrate this:

an instrument which makes you think things differently, i.e. 'be careful we are not alone' and 'results count' (. . .) It is essential, mainly, to give us instruments of monitoring, and evaluation and, above all, to know how to put the problems, what we can get, what we cannot get, what is important, what is not important. (...) We had educational system performance variables - dropout rates, level of schooling, approval and retention rates, etc., (. . . ) but then we lacked the output in terms of knowing the quality of education. It means moving from the idea of quantity of education to the quality of education (. . . ) (Former Minister of Education, Interview \#4, 2009).

[PISA] allows you to have knowledge about the results, the acquired ones, the competences, the quality of what is taught, of what one learns, with the international cooperation. It allows countries to realise that they have similar problems, allows countries to have common strategies. The field of education has always benefited greatly from international comparisons, because it is what enables countries to carry on updating their ambition (Former Minister of Education, Interview \#3, 2008).

Before PISA, we did not know exactly at what point we put in relation to the rest of the world (Former Minister of Education, Visão [weekly magazine], 14/09/2014).

We cannot run the risk of stagnation. We need to move forward. We aim to be in the front group, where the Asian countries are but also many European countries such as Ireland, Austria, Germany, Belgium or Finland. (Former Secretary of State for Basic and Secondary Education, Público [Daily newspaper], 4/12/2013).

Together with the script on the national political action oriented by results (and in particular by the results of PISA), a narrative on improvement, aligned with the OECD's visions, also emerges:

(. . .) because the goal of PISA (. . .) is to gradually bring us all closer to the higher levels, is to improve the averages so that people know more, go further in their education, have greater skills, have greater knowledge (...). (Former Minister of Education, Interview \#1, 2008). 
Our commitment to this process [joining PISA] is identical, not only in relation to PISA, but also by a process that opens then within the European Commission, when the European Commission wants to make a benchmarking in education (...) What interests me is that this benchmarking takes into account at least some of the variables: the way we progress and not how we are, or in other words, to introduce a dynamic and prospective analysis of the evaluation of education systems (. . .) the meaning of progression, that is, we were not interested in knowing if we are in 1st, 2nd or 3rd, if this is bad or worse, but how we are dealing with the problem, i.e., how we are overcoming the difficulties (Former Minister of Education, Interview \#4, 2009).

(. . .) for a process of permanent quality control, the role played by international testing such as PISA is important. By allowing the construction of comparative databases, they also contribute to the international production of benchmarks that serve as parameters for schools and countries to improve the quality of their work (Former Minister of Education, Governmental Website, 2007).

In short, the enactment of the script of the education system's internal improvement nurtures narratives that ascribe hope and belief to the steering of the systems on the basis of evidence.

\subsection{The difficult transformation of comparative knowledge for policy into knowledge for national policy: Signs of change}

Besides the assignation of legitimation and idealisation purposes to PISA texts and objects, policy-makers also present it as a primary or a supplementary source of information, as illustrated by the following quotes:

Obviously, I never thought that PISA was a kind of magic wand that would solve the problems of education, but it was an element that could bring us a lot of information, even for us to know a little better what we were doing (. . . ) (Former Minister of Education, Interview \#1, 2008).

The PISA study, this comparison, in a way, awakened those who had some responsibility and gave them an instrument, so to speak, to be able to support the decisions. (. . .) Now, I still think that, above all else, the effect of the publication of the results was important to demystify some ready-made thoughts. (...) It is important when I say that this process of international studies and of PISA was, above all, a leverage of reflection, of an awareness. Now, before taking measures I was not going to study the PISA report first, of course. (. . ) I think politics is valued if it can be based on substantiated information (Former Minister of Education, Interview \#4, 2009).

Then there are those who do not decide without information and those who consider information irrelevant to decide. (. . .) What I think is that - and that is why I said it's a very personal view and there may be some professional deformation here [sociologist] - I find it impossible to decide without having the necessary information to do so (...). I studied and analysed data and made a series of policy decisions based on PISA results, to which I added a few other elements which, however, I had asked to be collected and which seemed to me very important (Former Minister of Education, Interview \#3, 2008).

These quotations lead us to conclude that there is a gradation in the ways PISA is mobilised, from a resource to be consulted to a resource to be studied. And they also illustrate different types of political mobilisation of knowledge (Delvaux, 2009): to attest the need for a policy solution to a problem; to guide the preconisation and implementation of policies; to work as a sort of informational up-grade that keeps actors updated on the changes in the sector in which they intervene. These kinds of statements also remind us that informational mobilisations tend to vary according to actors' dispositions towards evidence-based policy-making approaches, and depending on them having ad-hoc or formal structures that are able to work with this kind of data (Pons, 2012, Carvalho, 2014). However, on the basis of the data we present here, one can only identify one common trait in the dispositions of the interviewed ministers: the recognition of the need for this type of information for political decision.

The absence/need of appropriate information is a key-issue for some of the interviewees: 
TABLE 2 The national management of PISA

\begin{tabular}{|c|c|c|c|}
\hline Cycle & $\begin{array}{l}\text { Entity responsible for the } \\
\text { National Management of PISA }\end{array}$ & $\begin{array}{l}\text { NPM: Main area of activity } \\
\text { along the professional path }\end{array}$ & $\begin{array}{l}\text { NPM: Area of knowledge } \\
\text { (highest qualification) / area of } \\
\text { expertise }\end{array}$ \\
\hline 2000 & $\begin{array}{l}\text { Central State Administration: } \\
\text { GAVE * }\end{array}$ & $\begin{array}{l}\text { University and Central State } \\
\text { Administration: }\end{array}$ & Psychology / Evaluation \\
\hline 2003 & $\begin{array}{l}\text { Central State Administration: } \\
\text { GAVE }\end{array}$ & Business management & Management (IT) \\
\hline 2006 & $\begin{array}{l}\text { Central State Administration: } \\
\text { GAVE }\end{array}$ & Business management & Management (IT) \\
\hline 2009 & $\begin{array}{l}\text { Central State Administration: } \\
\text { GAVE }\end{array}$ & State Administration & Sociology** \\
\hline 2012 & $\begin{array}{l}\text { Central State Administration: } \\
\text { ProjAVI//DGEE }\end{array}$ & University & Psychology / Statistics \\
\hline 2015 & $\begin{array}{l}\text { Indirect State Administration: } \\
\text { IAVE }\end{array}$ & University & $\begin{array}{l}\text { Physiology and Plant } \\
\text { Biochemistry /Statistics }\end{array}$ \\
\hline
\end{tabular}

*GAVE (Educational Evaluation Office) was a structure at ME in which the PISA National Centre was settled until 2013. Three reports were written by GAVE (GAVE, 2001, 2004, 2007).

**In 2009, GAVE produced only one synthesis (GAVE, 2010). A more extensive report was prepared, outside the GAVE, by a team coordinated by a qualified sociologist in quantitative methods ( $\mathrm{H}$. Carvalho), following a protocol between the $\mathrm{ME}$ and a research centre.

***ProjAVI - Project Group for the International Evaluation of Students - was created within the scope of the ME with the mission to coordinate, in Portugal, the international projects in the field of educational evaluation, having produced a report on PISA (ProjAVI, 2013).

****IAVE (Educational Evaluation Institute) is a structure integrated in the indirect administration of the State (endowed with pedagogical, scientific, administrative and financial autonomy) which arises following the extinction of GAVE. It generated reports on PISA 2015 (Marôco, 2016).

PISA helps to reflect and understand better, but it is not enough, we needed to complete our information and our knowledge from what PISA reveals, with finer, more in-depth studies (...) (Former Minister of Education, Interview \#3, 2008).

(...) the education system remains unvalued and this subjects us to the international criteria and to the international studies due to the lack of self-evaluation. And one of the things I was worried about was, in particular, to make it possible for the Conselho Nacional de Educação (CNE, National Education Council) ${ }^{1}$ to develop - although it had neither the money nor the know-how nor the competence to do so but that it was an institution outside the Ministry that could ensure such an evaluation system, that is, it could even be the Ministry to provide the statistics, provide all the information, the indicators, etc., but there should be a reading outside the structure, by the various [social partners] (Former Minister of Education, Interview \#4, 2009).

Regarding the production of information on the Portuguese education system based upon PISA results and databases, it is worth noting that there has been a regular production of reports for all the editions. Moreover, it is possible to describe a transformation of the profile of PISA National Project Managers (NPM) in Portugal (Table 2): from qualified officials at the Ministry of Education (profiles in the first three cycles) to academics with high qualifications in areas other than Education and further research specialisation in the field of statistics (last two cycles).

A parallel trend has been perceptible since 2009 regarding the publication of secondary analyses based on PISA data in journals and in the records of events that are expressly dedicated to the analysis of the Portuguese results in PISA by authors who have been associated with research centres and national universities (Table 3). 
TABLE 3 Fields of expertise of the authors of secondary analyses based on PISA data (2009-2016), considering the first national author

\begin{tabular}{|lll}
\hline Period & $\begin{array}{l}\text { Publications in Journals } \\
\text { ( } \mathbf{n}^{\circ} \text { of articles) }\end{array}$ & $\begin{array}{l}\text { Publications in } 2 \text { Seminar Books } \\
\text { ( }{ }^{\circ} \text { of chapters) }\end{array}$ \\
\hline $2009-2012$ & $\begin{array}{l}\text { Sociology (1) } \\
\text { Education (2) } \\
\text { Economy and Management (4) }\end{array}$ & Economy and Management (1) \\
\hline $2013-2016$ & Economy and Management (3) & $\begin{array}{l}\text { Education (1) } \\
\text { Economy and Management (5) }\end{array}$ \\
\hline
\end{tabular}

*Both publications are written by CNE, the event organiser (CNE, 2010, 2015). In the first, only one of the chapters presents a secondary analysis. The following chapters, of a different nature, are written by authors related to the field of education.

These data illustrate the emergence of actors who have expertise in qualitative methods, matching that which is required by the models that orient the production of PISA data, and/or who are willing to produce policy knowledge, especially drawing on problems and approaches from the fields of Economics and Management (in some cases also Sociology and Psychology). This does not mean that there has been an interruption or some sort of overshadowing of the productions generated in the field of educational research. It represents the continuity of the lack of secondary analyses based on PISA data generated in the field of educational research in Portugal, detected up to 2009 (Costa, 2011), which, in turn, relates to the absence of a strong tradition of quantitative studies in educational research in Portugal.

What may be of significance in terms of policy processes is the possibilities of more information directed towards policy spaces and, with that, of new frameworks (other world views on education and its governing), on the basis of which the original PISA data are translated for policy actors and are likely to be mobilised as a source of valuable information.

Another (recent) phenomenon related to the presence of PISA in the policy processes is the emergence in Portugal in 2015 and 2016 at the CNE of a project (and small-scale infrastructure) that is presented as a mediator between PISA knowledge and the public and the decision-makers. Named aQeduto (Aqueduct): Evaluation, quality and equity in Education, born of the initiative of the current leadership of the CNE and sponsored by the CNE and by a national philanthropic foundation ${ }^{2}$, it is deliberately oriented towards the production of information from PISA data-bases about the Portuguese students' results for policy-makers and lay persons. It intends not only to build 'credible and sustained information', but also 'explanations' regarding the 'variation of the results' of Portuguese students in the PISA tests 'in simple language but preserving scientific rigour'.(www.aqeduto.pt/apresentacao). Its coordinator is a former NPM (2012-2013) who has expertise in multivariate data analysis. The project team includes four other members - the President of the CNE, researcher and professor of Sociology in a public University, and former Minister of Education [2001-2003]), a coordinator for data analysis who studied Economics, another researcher and professor of Sociology in a public university, and a member of the scientific and technical advisory team of the CNE. ${ }^{3}$ The team embraces quantitative approaches to Psychology and Sociology, and Economics, which illustrate the importance of data and data sciences in the production of knowledge on education in Portugal as elsewhere (Ozga, 2012).

In the past year, the project has produced small pieces of secondary analysis on 10 themes on a monthly basis (e.g., Does grade repetition improve learning outcomes? What makes a good school?), together with several exchange and publication activities. These practices of continuous mediation between PISA texts and the world of politics and public action by a collective actor that was until recently simply playing its appointed role, producing recommendations and promoting consensus, may well be a sign of new phenomena in the national reception of PISA: the role of the knowledge-policy broker, as there is the intention of translating knowledge that is carried from one social world to another and thus connecting those worlds (Delvaux, 2009); the role of the knowledge entrepreneur, as there is the intention of creating an organisation through the mobilisation of various resources and actors around a specific agenda in which experts play a central role (Van Zanten \& Pons, 2006). ${ }^{4}$ 
TABLE 4 Corpus

\begin{tabular}{|c|c|c|}
\hline Newspaper & Title & Author \\
\hline Correio da Manhã (7/12, p.31) & Great news & Mayor of Lisbon / Newspaper Columnist \\
\hline Diário de Notícias (7/12, p.11) & We improved! We can still improve! & $\begin{array}{l}\text { Minister of Education (2011-15) / } \\
\text { Scholar (applied mathematics) }\end{array}$ \\
\hline Diário de Notícias (7/12, p.11) & $\begin{array}{l}\text { PISA 2015: quality and equity in educa- } \\
\text { tion }\end{array}$ & $\begin{array}{l}\text { Minister of Education (2005-09) /Scholar } \\
\text { (sociologist) }\end{array}$ \\
\hline Público (7/12, p. 44) & A big round of applause for our schools & Journalist \\
\hline Público (8/12, p. 48) & $\begin{array}{l}\text { Justice for Nuno Crato [Minister of } \\
\text { Education (2011-15)] }\end{array}$ & Columnist (politics and society) \\
\hline Público online (8/12) & $\begin{array}{l}\text { Parents and mothers of Portuguese } \\
\text { students' success }\end{array}$ & Journalist specializing in education \\
\hline Expresso $(10 / 12$, p.2) & $\begin{array}{l}\text { Reality runs over the ministers of } \\
\text { education }\end{array}$ & Journalist/Columnist \\
\hline Expresso $(10 / 12$, p.34) & What difference does it make? & $\begin{array}{l}\text { Columnist and political commentator/ } \\
\text { Scholar (Social and political sciences) }\end{array}$ \\
\hline Expresso $(10 / 12$, p.35) & That lost decade & Journalist/Columnist \\
\hline Expresso $(10 / 12$, p.35) & Our best results ... to date! & $\begin{array}{l}\text { Minister of Education (2011-15) / } \\
\text { Scholar (applied mathematics) }\end{array}$ \\
\hline Público online (12/12) & School success has no owner & State Secretary for Education (current) \\
\hline Público online (12/12) & PISA 2015, sloping results? & Member of parliament \\
\hline Expresso online (12/12) & A matter of education & Columnist (economy) \\
\hline
\end{tabular}

\section{3 | THE POLITICAL RECEPTION OF PISA 2015: AN EXPLORATORY INCURSION THROUGH THE PRESS}

Here, we analyse the reception of PISA 2015 in the Portuguese press. More precisely, we analyse the interventions by political actors in the Portuguese daily and weekly written press (not the press coverage of the PISA 2015 results). Thus, we only consider texts that are published as an expression of its author's opinion and we only cover a one-week period, starting on 6 December, the date of the public presentation of results (Table 4).

We organise the content analysis according to two axes: how is PISA observed by the authors of articles about its results; which are the main themes that emerge from the observations they produce about the PISA 2015 data. Two main lines emerge from our analysis: the reception of the 2015 data as a further moment for the consecration of PISA's credibility; the use of the results, in this short period of reception, for processes of qualification and disqualification of educational policies and perspectives, directed both towards the past and the future.

\subsection{Strengthening the status of PISA}

Regarding the way PISA is observed by the authors of the article, two complementary elements are significant: the absence of objections to PISA ${ }^{5}$ and the further credibility ascribed to it. This consecration occurs in various ways: through the use of positive adjectives for PISA or through the qualities that confirm its value: its dimension, data richness, reputation, seriousness, expertise; and through the presentation of PISA data and results as a mirror of reality and through confident judgements of policies on the basis of the variation of results. And it also happens through statements that confirm OECD views on PISA: it measures the quality of student learning in each generation; it drives countries to develop regular reflection practices; it breaks down ready-made ideas on education. ${ }^{6}$ 
A final association is identified in the corpus that presents PISA as an element for the ordering of political life in the education sector and for the governability of the education system. It is suggested to revise the national exams, as these are not showing the same progress as in the PISA results. And there is the appreciation of the existing consensus about the credibility of PISA assessment as a sign of a (desired) change in the way public policy is carried out in Portugal - on the basis of evaluation rather than ideological prejudices. This understanding of PISA as a regulating device of other regulating devices and of the policies themselves places it at another level: as 'third-party evaluator' in social processes of 'surveillance and interpellation' of public authorities' interventions (Cattonar \& Mangez, 2014, p. 68).

\subsection{The interpretation of results within the course of public policies}

Portuguese students' results were better than those of all the previous cycles and, for the first time, they are higher than the OECD average for the three literacy fields (Figure 2). In this scenario, it was the power of praise and hope, not that of guilt, which mostly emerged in the texts. ${ }^{7}$ Thus, the acknowledgement of progress is present in all. But only in a few cases are the gains simultaneously attributed to overall improvements in performances and to improvements of specific groups of students.

The content analysis of the observations by the authors of the articles shows three recurrent themes in which there are significant elements of tension: explanations for the observed improvement of results; qualification/disqualification of policies on the basis of the results; and required policies on the basis of the results.

When explaining the progresses on the basis of PISA 2015 results, the arguments concentrate on 'to whom' and/ or 'to what' might the success be attributed (although with no mention of data or information from PISA 2015 reports, except in three cases). And they cross two distinct subject-matters: the extent and the combination of the considered explanatory factors; and the time-span required to validate the existence of public policies effects upon the results.

In the first case, most texts tend to assign responsibility to a wide range of actors (and factors): teachers (work, competence and endurance in adverse circumstances); families (levels of parental education and expectations regarding school trajectories); ministers (competence); students (for their work). Only a few refer to a combination of factors, and those who do it assemble very disparate factors, rarely apprehended in a systemic manner.

But all the texts go on, and more profusely, about policies, which thus reinforces the perception that policies may make a difference. Most authors consider various public education policies introduced since the middle of the last century, but there is a debate on whether or not policies pursued by the last government have an effect on the results. It is a reaction that is found in several texts published after the previous minister [2011-2015] claimed an effect of his policies on the results (December 7). Some texts do directly target the minister and counter-argue, others recall the need to consider a wider time frame.

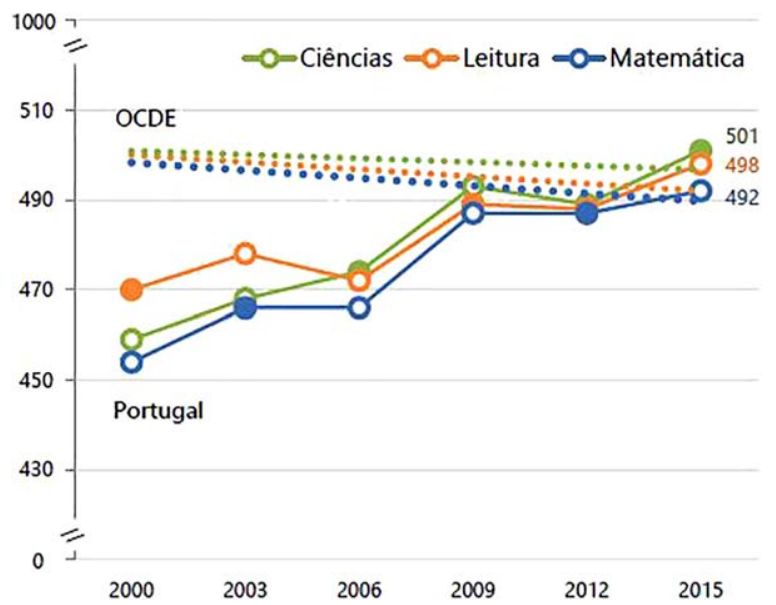

FIGURE 2 - Scores obtained by Portuguese students who were assessed by PISA, 2000-2015

(Source. Marôco, 2016, p. 9) 
TABLE 5 Apologies and criticisms in the 'observation' of the results

\section{Qualified}

Public Policies
Extension of pre-school education

Priority intervention

Differentiation of pedagogical practices

Strengthening the quality of school

spaces

Exams, curriculum standards, rankings Horizontal stratification (vocational courses in basic education)

\section{Discourses}

The demand for results

The culture of 'exigency'

\section{Disqualified}

Horizontal stratification (vocational courses in basic education)

Educationalists culture of complacency Loss of quality of the education system Inability of the school to promote social mobility

The (strictly) economic function of education

Still, although not referring to concrete interventions of the last government, several texts associate the improvement with the banner of its policies and with the discourse on the Portuguese school that it embodied in the previous decade: 'exigency'. Consequently, the divide on whether or not to consider the most recent interventions is embedded in a broader one, between those who defend educational perspectives that may be associated with the intervention of centre-left or centre-right governments. This divide is perceived at two interconnected levels: qualification/disqualification of policies; and qualification/disqualification of discourses (Table 5).

Combining the beliefs actors carry to the public action and the pragmatism of the political action (Barroso, 2009), the reception of PISA 2015 becomes a privileged space for the activation of scripts elaborated in the past and, also, in an exercise for the differentiation of views on education. However, it is also a space for the aggiornamento of orientations. This phenomenon is particularly evident in the way texts written by actors related to the centre-left almost entirely abandon the defence and the widespread use, mostly between 2005 and 2009, of pervasive evaluation policies (of students, teachers and schools). Of this former attachment to evaluation little remains: the promotion of the external evaluation of schools is remembered in only one of the analysed texts; the invocation of ideas associated with the "policy evaluation" movement (Pons, 2011) and the so-called evidence-based policy by actors connected to the university world, in line with the way in which they give credibility to PISA as a reference instrument for policies.

This withdrawal of the assessment policies from the discourse of the centre-left (and of the current government [2015-....]) cohabits with a (new) agenda in which the problem of (excessive) grade repetition is highlighted, a question identified long ago by OECD as a negative feature of the Portuguese system. Thus, some texts offer arguments for the fight against grade repetition and in favour of diagnosis and early intervention in order to meet that end. Furthermore, in the ceremony for the presentation of PISA 2015 results, grade repetition was the subject that reporters mostly captured because of the focus on the matter by those in charge of the management of PISA in Portugal and by the Minister of Education for whom 'PISA recommendations are mirrored in the government programme (http://expresso.sapo. pt/sociedade/2016-12-06').

In other texts, the 'grade repetition agenda', backed by the mobilisation of analyses present in the 2015 reports and by the OECD 'tutelary shade', is opposed by calls for the preservation of standardised assessment policies, which were intensified in Portugal between 2011 and 2015, and for the discourse in favour of 'exigency' and of a 'focused and assessable' education, based on exams, as well as in favour of horizontal stratification with vocational courses in basic education. Some also claim to find in PISA support for such a solution.

\section{4 | CLOSING REMARKS}

In the last 15 years, a reciprocal legitimating relationship between PISA and the policy actors was established and consolidated in Portugal. 
There is a selective mobilisation of knowledge, in such a way that recurrent public policy questions are kept, come back, or achieve greater visibility as educational and public agenda problems, according to the tendencies imposed by the results and by the political orientation of the contenders. If the credibility ascribed to the knowledge generated within PISA offers its national users added legitimacy for debating and proposing policy measures, such insistent use (even if superficial) adds authority to the survey and to the scripts it carries. Hence, it seems clear that, in Portugal also, the use of PISA credibility for the benefit of the ideas and policies to be included - or kept in the policy agenda and to be implemented is somehow superimposed on the expected rationalisation of public action. This observation supports the hypothesis that 'knowledge for learning' processes are rarely considered when the actors mobilise PISA data to elaborate arguments about their systems (Pons, 2012). In any case, in view of the existing studies, the question of what politicians (and, more generally, public policy in Portugal) have learned from the use of the 'mirror' remains open.

The analysis of the PISA trajectory in the policy processes in Portugal reveals what the literature on knowledgepolicy relationships has been exposing for many years: the impact of research knowledge on policies depends on a combination of elements, such as the level of the policy actors' knowledge and expertise on the subject, or the compatibility between that knowledge and actors' ideological compromise or strong interests (Weiss, 1990). It also seems clear that the critical factors for the presence of comparative assessment knowledge in policies relate to the origin and type of knowledge, to the ways in which knowledge is mobilised, to the contextual and interest-related features of political action and to the historicity of the rules and beliefs that guide it. In this context, the emergence in Portugal of new actors and ways of translating PISA data/information/knowledge for policy is a trace of originality in the processes of reception that requires further observation.

In sum, PISA data and analysis open and close routes and establish a set of possibilities for policies. Mobilised in various sociocultural spaces, PISA is acted upon by systems of meaning and power relations, which it also helps to rewrite, thus producing specific effects (Popkewitz, 2003). Hence, the regulatory role of PISA seems clear: it enables the emission of judgments about the school systems, the construction of opinion on policy decisions, and the reasoning of decisions based on knowledge perceived as 'real'. Of course, this does not come out from the evaluation per se. The politics of reception are also an important part of this.

\section{NOTES}

${ }^{1}$ The CNE is an education policy consultancy body of the Ministry of Education (ME).

2 The philanthropic foundation, Fundação Francisco Manuel dos Santos, was created by a Portuguese economic group. It publishes, funds research, promotes discussions on various social issues, working with 'experts' and producing data on Portugal and Europe. https://www.ffms.pt/en/about-us/2/mission-and-goals Accessed 02/12/2016

${ }^{3}$ In an earlier phase of the project, the team also included one other member who had previously worked (2008-2011) as an NPM at the GAVE.

${ }^{4}$ The presentation by the President of CNE at a seminar on PISA results is an important source for our exploratory analysis (Justino, 2015).

${ }^{5}$ There are some considerations on methodological questions (and on a possible exclusion of students who follow a vocational path), but the authors reproach national policies and do not blame the survey. Such a possible exclusion was later denied by the National Programme Manager, in 12/12.

${ }^{6}$ None of the authors of the opinion articles published in the first week is related to teacher unions or parent associations. On December $6^{\text {th }}$, one of the teacher organisations published on its website (Federação Nacional dos Professores, http://www. fenprof.pt/ aba $=27 \&$ mid $=115 \&$ cat $=226 \& d o c=10631$ ), a text by Education International (El) where El praises proposals for the improvement of equity and criticises the fact that OECD fails to consider the 'impact of qualified teachers, small classes and adequate resourcing' on the quality of education systems. Under the title 'PISA 2015 highlights Portuguese students' results - the schools' work has its effects', one other teacher organisation recognises the need for 'great caution' in data analysis 'to avoid misinterpretations', but takes PISA results as a 'truly relevant information source for all decision makers' and praises the inclusion of policy proposals in the 2015 report that 'meet orientations' advocated by this teachers' union (Federação Nacional de Educação, http://www.fne.pt/pt/noticias/go/atualidade-relat-rio-pisa-2015-sublinha-resultados-dos-alunos-portugueses-o-trabalho-das-escolas-tem-efeitos).

${ }^{7}$ One text questions if the improvement could result from horizontal stratification policies, which the author associates with a possible exclusion of students from the assessment. See note 5 . 


\section{REFERENCES}

Afonso, N., \& Costa, E. (2011). A circulação e o uso do PISA em Portugal. In L.M. Carvalho (org.). O espelho do perito (pp. 107-125). Gaia. FML.

Barroso, J. (2009). A utilização do conhecimento em política. Educação \& Sociedades, 30, 987-1007.

Carvalho, H., Ávila, P., Nico, M., \& Pacheco, P. (2011). As competências dos alunos. Resultados do PISA 2009 em Portugal. Lisboa: CIES-IUL.

Carvalho, L. M. (2014). The attraction of mutual-surveillance of performances. In T. Fenwick, J. Ozga \& E. Mangez (Eds.), World yearbook of education 2014: Governing knowledge (pp. 58-72). Oxford: Routledge.

Carvalho, L. M., \& Costa, E. (2016). The praise of mutual-surveillance in Europe. In R. Normand \& J.-L. Derouet (Eds.), A European politics of education? (pp. 53-72). London: Routledge.

Carvalho, L. M. \& Costa, E. (2009). Production of OECD's PISA: Final report. Project KNOWandPOL. http://www.knowandpol.eu/

Cattonar, B., \& Mangez, E. (2014). Codages et recodages de la réalité scolaire. Revue Internationale d'Education de Sèvre, 66.

CNE (2010). Impacto das avaliações internacionais nos sistemas educativos. Lisboa: CNE.

CNE (2015). Investigação em educação e os resultados do PISA. Lisboa: CNE.

Costa, E. (2011). O PISA como instrumento de regulação das políticas educativas. Tese de Doutoramento. Universidade de Lisboa, Instituto de Educação.

Delvaux, B. (2009). Qual é o papel do conhecimento na acção pública? Educação \& Sociedade, 30, 959-985.

Fernandes, D. (2014). Avaliações externas e melhoria das aprendizagens dos alunos, In CNE, O estado da educação 2014. Lisboa: CNE.

GAVE (2001). Resultados do estudo internacional PISA 2000. Lisboa: ME/GAVE.

GAVE (2004). Resultados do estudo internacional PISA 2003. Lisboa: ME/GAVE.

GAVE (2007). PISA 2006 - Competências científicas dos alunos portugueses. Lisboa: GAVE.

GAVE (2010). PISA 2009 - Competências dos alunos portugueses: síntese dos resultados. Lisboa: Lisboa: GAVE.

Justino, D. (2015). Abertura. In CNE, Investigação em Educação e os Resultados do PISA (pp. 3-17). Lisboa: CNE.

Marôco, J. (coord.) et al. (2016). PISA 2015 - Portugal. Volume 1. Lisboa: IAVE.

MEC (2015). Educação pré-escolar, ensino básico e secundário. Relações internacionais. 2011-2015. Lisboa: MEC.

Ozga, J. (2012). Knowledge stocks and flows: Data and education governance. In T. Fenwick \& L. Farrell (Eds.), Knowledge mobilization and educational research. London: Routledge.

Pons, X. (2011). Policy evaluation in education in France. Educação, Sociedade \& Culturas, 34, 35-50.

Pons, X. (2012). Going beyond the 'PISA shock' discourse: An analysis of the cognitive reception of PISA in six European countries, 2001-2008. European Educational Research Journal, 11, 206-226.

Popkewitz, T. (2003). National imaginaries, the indigenous-foreigner, and power. In J. Schriewer (Ed.), Discourse formation in comparative education (2nd edition) (pp. 261-294). Frankfürt: Peter Lang.

ProjAVI (2013). PISA 2012, Portugal - Primeiros resultados. Lisboa: ProjAVI.

Steiner-Khamsi, G. (2004). The global politics of educational borrowing and lending. New York: Teachers College Press.

Van Zanten \& Pons (2006). Knowledge circulation, regulation and governance. In Aa.Vv. KNOWandPOI Literature Review, Vol I. http://www.knowandpol.eu/

Weiss, C. (1990). The uneasy partnership endures: social science and government. In S. Brooks \& A.-G. Gagnon (Eds.), Social scientists, policy, and the state. New York, NY: Praeger.

How to cite this article: Carvalho LM, Costa E, Gonçalves C. Fifteen years looking at the mirror: On the presence of PISA in education policy processes (Portugal, 2000-2016). Eur J Educ. 2017;00:1-13. https://doi.org/ 10.1111/ejed.12210 